\title{
Dams, Environment and Local People
}

\section{A.B. Thapa}

\begin{abstract}
Dams, environment and local people are interrelated. Large dams have several large scale advantages in irrigation, flood control, power generation, inland navigation etc. It is equally true that it has also many large scale adverse impacts inducing controversy and disputes. For example, despite enormous benefits to Canada from large scale dams, the local people of the Basin are still feeling deep resentment at the way they were treated. Hence, it is utmost necessary to thoroughly examine all the important aspects of the project particularly the environment side regarding the implementation of large dams.
\end{abstract}

Large dams can be very beneficial. They can provide regulated flow to generate abundant hydroelectric energy. Similarly it would be possible to boost agriculture production by supplying regulated water for irrigation in the dry season when the demand for water is the highest. There can be several other advantages of building dams, including flood control and inland navigation.

When the nature of the benefits is analyzed, we find that dams benefit mostly the downstream regions while it impoverishes people living in upstream areas. In our case, India and perhaps Bangladesh would also benefit from dams constructed in Nepal, while our country would bear the brunt of adverse environmental impacts. Unfortunately, politicians, planners and entrepreneurs in Nepal tell the public that the livelihoods of local people will be greatly improved by implementing large hydropower projects such as the West Seti, Karnali-Chisapani, Tama-Kosi, Kali-Gandaki-2, Buri-Gandaki, and Andhi Khola projects, which are storage type projects. Is it really true that the people will be better off after the implementation of large storage dam projects? Or it is merely a deception? For comparison, let us see what the river basin residents of Canada are saying now 30 years after the implementation of the Columbia River storage dam projects.

Columbia River dam projects have provided enormously large benefits to Canada. Apart from the direct power benefits generated at hydropower stations in Canada, that country has received a large sum of money from the USA in return for flood control benefits to accrue to latter. In addition, Canada is receiving from the USA, in perpetuity, $50 \%$ of the additional power generated at 11 downstream hydropower stations, in return for providing the water storage. Despite the fact that Canada took full advantages of the Columbia River dam projects, the people living in the Columbia river basin still feel deep resentment at the way they were treated. The following are the excerpts from Canadian reports.

\section{Basin people in Canada bitter about projects}

In 1967 an American resource economist predicted that the Columbia River Treaty would provide an economic 'shortfall' for the Columbia Basin. Today that loss is considered incalculable. If negative environmental and social impacts are considered, the effects on the region are even more aggravated. The Basin bears the symptoms of the negative Treaty impacts with lower development and economic growth in many parts of the Basin, particularly those areas affected most directly by the reservoirs. The resentment and bitterness over how the region was treated 30 years ago is still in the minds and memories of many Columbia Basin residents.

The Treaty dams created four reservoirs flooding 60,00o hectares of land in the Columbia Basin. Included in the flooded land were dozens of small communities and thousands of acres of farmland and harvestable forest. The reservoirs damaged a regional fishery already crippled by the loss to other dams on the Columbia River. The flooding destroyed precious wildlife habitat and turned pristine natural lakes into huge fluctuating industrial reservoirs. The Arrow Lakes reservoir, for example, can rise and fall seven stories in height at the beach at Nakusp. During recent drought years, Valemount residents have had to drive more than 20 miles on lake bottom from their community dock on the Kinbasket reservoir to find water. As well as destroying potential wealth, the reservoirs have acted as barriers to resource development in parts of the region. Perhaps the worst impacts were the human costs. Thirty years ago more than 2,300 Basin residents were uprooted and moved from their homes and, in many cases, from their livelihoods to make way for the reservoirs. 


\section{The case of Nepal}

\section{Loss of agricultural production}

The valley bottoms of all major Nepalese rivers are extensively cultivated with paddy, maize, cereals, pulses and mustard being the most common crops. Reservoir formation would eliminate these cultivated lands resulting in an enormously large loss in agricultural production

\section{Large numbers of people evicted}

The areas to be submerged by the proposed storage reservoirs in Nepal are densely populated. According to a 1979 UNDP study, about 47,000 people would be displaced to implement the 360 MW Kali-Gandaki 2 storage project. Similarly, in the same study, it was estimated that about 22,000 and 14,000 people would be displaced with the implementation of the 180 MW Andhikhola and 460 MW Buri-Gandaki projects, respectively. These are the storage projects selected by the government to be implemented in near future.

\section{Earthquakes danger}

The geotectonic lines in Nepal that determine the geological structure of the Basin consist of two major thrusting faults-the Main Central Thrust (MCT) and the Main Boundary Fault (MBF). These faults extend in an east-west trend across Nepal, acting as the major division between formation groups.

The formation of a large reservoir overlying tectonically active and faulted areas would lead to an increase in seismic events. An existing dam at Koyna in India, for example, is believed to have triggered an earthquake of magnitude 6.3.

\section{Dams at the center of controversy}

The World Commission on Dams recently published the report Dams and Development (2000), providing in-depth information on issues related to dams. A few of the issues are discussed here.

Dams have made an important and significant contribution to human development, and the benefits derived from them have been considerable. In too many cases, however, an unacceptable and often unnecessary price has been paid to secure those benefits in both social and environmental terms by displaced people and by the natural environment.

Dams are at the center of controversy, dispute, and even violent confrontation. There are many reasons largely related to the scale and scope of the dams and the impacts.

\section{Impact of dams on local people devastating}

Large dams are unique among major infrastructure projects in terms of the scope and manner in which they affect the pattern of access to resources, and in their distribution across space, time and social groups. They are generally justified by national or regional macro-economic benefits while their physical impact are locally concentrated, mostly affecting those within the confines of the river valleys and along the river reaches.

Large dams have significantly altered many of the world's river basins, with disruptive, long-lasting and usually involuntary impacts on the livelihoods and socio-cultural foundations of tens of millions of people living in the region. The impacts of dam-building on people and livelihoods-both above and below damshave been particularly devastating in Asia, Africa and Latin America where, in the past, existing river systems supported local economies and lifestyles of large populations in diverse communities.

\section{Local people ruined}

Dams take a set of resources-a river and the lands along its banks, generating food and livelihood for local people, and transform them into another set of resources-a reservoir, hydropower and irrigation, providing benefit to people living elsewhere. There is a sense, therefore, in which large dams export river water and lands, removing them from the productive domain of one community to make them available to another. 
The Grand Coulee in the USA's Washington state provides a vivid example. Native Americans were physically displaced by the project in order to provide power to industry and to households in a city some $250 \mathrm{~km}$ away. Furthermore the water and land that had previously supported their livelihoods was dammed and diverted to provide white settlers with irrigated farming

\section{Resettlement problems}

Resettlement for large dams tends to be on a larger scale than resettlement associated with other types of physical infrastructure. Roads and thermal power plants, for example, can be sited on marginal land, whereas dams generally flood rich and fertile agriculture land. Those resettled from dam or reservoir sites often lose not only their homes but also their livelihoods. Relocation in rural settings where good land is already occupied can be problematic.

\section{Rio principle and the environment}

In 1986 the UN General Assembly adopted the Declaration on the Rights of Development (DRD). It marked a significant step by the international community towards developing a normative framework that specifies responsibilities in applying a human rights approach to development. It moved beyond the sphere of individual human rights to address relationships between different interest groups in society and their interaction with the state. In June 1992, the United Nations Conference on Environment and Development adopted a declaration usually known as the Rio Principles. Several of the principles are of immediate relevance to water and energy resources management. Principle Three, for example, recognizes the right to development, but insists that it be met in an equitable way that considers future generations as well as present participants in development. Principle Four insists that sustainable development requires that the environment to be integrated with the development process and form a central feature of the aim of that process.

\section{In Conclusion}

At present, Nepal is seen to be in a haste to make deals with private developers to implement large storage dam projects. If decisions are taken to implement such projects without thoroughly examining all important aspects, particularly the environmental side, the result will certainly be harm to our country.

Anand Bahadur Thapa holds a PhD degree in hydropower. He was Associate Member of RONAST and Member Secretary of the Water and Energy Commission. He writes and publishes papers regularly in water resources and hydropower. At present, he works as a freelance expert in water resources. 